\title{
Pembelajaran Membuat Resensi Drama dengan Teknik Think Talk Write pada Siswa Kelas XI Bahasa SMA Negeri 1 Cileunyi, Bandung
}

\author{
Henri Henriyan Al Gadri ${ }^{1}$ \\ ${ }^{1}$ Universitas Mathla'ul Anwar Banten
}

\begin{tabular}{ll} 
ARTICLE INFO & ABSTRACT \\
\cline { 2 - 3 } $\begin{array}{l}\text { Article History: } \\
\text { Received 21.07.2018 }\end{array}$ & $\begin{array}{l}\text { This study discusses about the ability of researchers and students in learning to } \\
\text { meceived in revised } \\
\text { form 20.08.2018 }\end{array}$ \\
Accepted 19.09.2018 & $\begin{array}{l}\text { to get an overview of the ability of researcher in the planning and } \\
\text { implementation of learning, the ability of students to review drama and the } \\
\text { Available online }\end{array}$ \\
effectiveness of think talk write technique used in learning to make drama \\
reviews. The method used in this study is a quasi-experimental method. The \\
result of this study shows that the researcher is able to carry out learning to \\
review drama with think talk write technique, which is proven by the value \\
obtained at 3.68 with a percentage of $92.25 \%$, students are able to make drama \\
reviews with think talk writing techniques as evidenced by the average score of \\
4.2 and the average value of post-test 8.45 with a difference of 4.2, and think talk \\
write techniques is effective to use in learning drama review based on the tcount \\
test of (5.67) ttable of (2.04) at the significance level of $5 \%$ with a confidence level \\
of $95 \%$ of the degree of freedom 19.
\end{tabular}

Keywords: Drama Review, Learning, Thinks Talk Write Technique.

DOI: $10.30653 / 006.201811 .6$

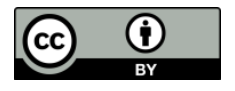

This is an open access article distributed under the terms of the Creative Commons Attribution 4.0 International License, which permits unrestricted use, distribution, and reproduction in any medium, provided the original work is properly cited. ๑ 2018 Henri Henriyan Al Gadri.

\section{PENDAHULUAN}

Resensi drama merupakan suatu kegiatan yang salah satunya bertujuan untuk memberikan penilaian dan memperkenalkan karya. Menurut Keraf (1994:274) bahwa resensi adalah suatu tulisan atau ulasan mengenai nilai sebuah hasil karya atau buku. Kegiatan merensensi baik bagi siswa dalam mengapresiasi suatu karya sastra, seni atau pun bentuk karya lainnya. Keterampilan menulis siswa dapat dilatih melalui kegiatan resensi. Selain itu, memberikan ruang kepada siswa untuk mengapresiasiasi suatu karya. Hal tersebut berpengaruh bagi perkembangan siswa dari segi kognitif, afektif, dan psikomotorik. Kegiatan resensi siswa dapat beroleh sesuatu yang di antaranya yaitu 
pengetahuan dari apa yang diresensinya, berpikir kritis dalam menyikapi objek yang diresensi, dan keterampilan menulis.

Kegiatan resensi mengajak siswa untuk menghargai karya orang lain, karena dari proses resensi terdapat kegiatan membaca atau pun menyimak sehingga dapat memahami dan mengenal karya orang lain. Djuharie (2005:21) menjelaskan bahwa resensi merupakan salah satu upaya menghargai tulisan atau karya orang lain dengan cara memberikan komentar secara objektif. Selain menghargai karya orang lain, mengajak siswa untuk gemar menulis. Menulis resensi merupakan suatu keterampilan yang bermanfaat bagi siswa di kedepannya. Dari kegiatan resensi dapat memicu siswa untuk produktif dikegiatan menulis lainnya seperti menulis artikel, esai, opini, berita dan prosa.

Membuat resensi dapat diajarkan kepada siswa seperti membuat karya-karya lainnya. Pada kurikulum Bahasa dan Sastra Indonesia pun terdapat materi tentang membuat resensi drama seperti pada Kurikulum Tingkat Satuan Pendidikan (KTSP) Mata Pelajaran Bahasa dan Sastra Indonesia kelas XI Program Bahasa terdapat standar kompetensi (SK) memahami kegiatan pementasan drama dan kompetensi dasar (KD) membuat resensi tentang drama yang ditonton. Oleh karena itu, tepat membelajarkan siswa membuat resensi drama yang ditonton.

Untuk menciptakan pembelajaran yang menarik dan menyenangkan, guru harus menggunakan suatu teknik pembelajaran yang bervariasi. Jadi, seorang guru harus mampu memilih teknik pembelajaran yang tepat digunakan dalam proses pembelajaran.

Salah satu teknik pembelajaran yang mengajak siswa untuk berpikir, berbicara dan menulis yaitu teknik think talk write. Think Talk Write sebagai dalam proses pembelajaran diharapkan mampu membangkitkan motivasi dan rangsangan kegiatan belajar siswa, membantu keefektifan proses pembelajaran, mengarahkan perhatian siswa untuk berkonsentrasi kepada isi pelajaran, memperlancar pencapaian tujuan untuk memahami dan mengingat informasi yang diberikan, pembelajaran menjadi lebih menarik, membawa variasi baru bagi pengalaman belajar siswa sehingga siswa tidak bosan (Tytler dalam Yamin dan Bansu Ansari, 2009:87).

Menurut Yamin dan Bansu Ansari (2009:84) bahwa, secara garis besar, think talk write (TTW) merupakan teknik pembelajaran yang menuntut siswa untuk berperan aktif dalam proses belajar-mengajar melalui tiga tahapan yaitu :

1) think, merupakan proses berfikir yang dimulai dari penemuan informasi baik dari luar maupun dari diri siswa sendiri, pengolahan, penyimpanan dan pemanggilan kembali informasidari ingatan siswa;

2) talk, yaitu berkomunikasi dengan kata-kata yang mereka pahami;

3) write, menuliskan dan mengktruksi ide setelah berdiskusi dan berdialog antar teman dan kemudian mengungkapkannya melalui tulisan.

Dapat disimpulkan bahwa teknik think talk write merupakan teknik yang menekankan pada proses berpikir, berbicara dan menulis. Teknik tersebut dapat digunakan dalam pembelajaran membuat resensi drama karena proses berfikir disana bisa didapatkan dari proses mendengarkan/menyimak lalu berbicara dalam kegiatan diskusi dan menuliskan suatu karya baru dari berpikir dan berbicara. 


\section{METODE}

Dalam penelitian ini, metode yang digunakan adalah metode kuasi eksperimen. Metode penelitian kuasi eksperimen dengan jenis one group pretest-posttest design, dimana dalam penelitian ini bertujuan untuk mengetahui keefektifan suatu metode mengajar dengan terlebih dahulu melakukan prates terhadap sampel penelitian sebelum diberi perlakuan kemudian baru diadakan pascates (Subana dan Sudrajat, 2009:99). Teknik penelitian yang digunakan ialah telaah pustaka, observasi, uji coba dan tes dengan teknik analisis data mengunakan rumus statistik pada distribusi frekuensi untuk prates, distribusi frekuensi untuk nilai pascates, dan analisis penilaian pembelajaran. Metode penelitian kuasi eksperimen digunakan dalam penelitian ini untuk menguji pembelajaran membuat resensi drama dengan teknik think talk write pada siswa kelas XI Bahasa SMAN 1 Cileunyi.

\section{PEMBAHASAN}

Kesuksesan proses pembelajaran tidaklah mudah didapatkan. Perlu beberapa tahapan-tahapan dalam mendapatkan keberhasilan tersebut. Dari segi perencanaan hingga pelaksanaan harus ditempuh dengan baik dalam prosesnya.

\section{Persiapan dan Pelaksanaan Pembelajaran}

Penilaian guru bidang studi Sastra Indonesia SMAN 1 Cileunyi, dalam pelaksanaan pembelajaran pada dasarnya ditujukan untuk mengetahui kemampuan peneliti, baik dalam kegiatan persiapan maupun dalam pelaksanaan pembelajaran atau kegiatan pembelajarannya. Untuk mengetahui tingkat kemampuan peneliti dalam proses belajar mengajar peneliti menggunakan nilai kuantitatif (angka) dengan kriteria penilaian 3,5 4,0 predikat baik sekali, 2,5-3,49 predikat baik, 1,5-2,4 predikat cukup, dan kurang dari 1,5 berpredikat kurang.

Peneliti mendapatkan nilai rata-rata 3,69 dari kegiatan persiapan dan pelaksanaan pembelajaran. Dengan demikian sesuai kategori nilai, maka peneliti memeroleh nilai dengan kategori baik sekali (A) pada proses belajar mengajar membuat resensi drama dengan teknik think talk write pada siswa kelas XI Bahasa SMAN 1 Cileunyi.

Untuk mengetahui persentase keberhasilan peneliti dalam mengajarkan membuat resensi drama yang ditonton dengan teknik think talk write, peneliti menetapkan batas keberhasilan sebesar $60 \%$ dan skor ideal 4. Diperoleh nilai rata-rata sebesar 3,69 dengan skor 4. Maka keberhasilan peneliti dari kegiatan belajar mengajar membuat resensi drama dengan teknik think talk write adalah 92,25\%.

Dengan demikian peneliti berhasil melaksanakan persiapan dan pelaksanaan pembelajaran membuat resensi drama dengan teknik think talk write pada siswa kelas XI SMAN 1 Cileunyi. Peneliti mendapatkan nilai rata-rata 3,69 dengan persentase 92,25\% dan berkategori baik sekali (A).

\section{Hasil Analisis Data Prates dan Pascates}

Data hasil pembelajaran membuat resensi drama yang ditonton didapatkan melalui pelaksanaan prates dan pascates. Prates dilaksanakan sebelum pembelajaran dimulai atau biasanya disebut tes awal. Sedangkan Pascates dilaksanakan setelah pembelajaran dilaksanakan yang bertujuan untuk mengetahui kemampuan dalam menerima materi, sehingga biasanya disebut tes akhir.

Nilai prates dan pascates siswa kelas XI Bahasa SMAN 1 Cileunyi dapat dilihat pada table distribusi nilai berikut ini. 
Tabel 1. Distribusi Frekuensi Nilai Prates Siswa Kelas XI Bahasa SMA Negeri 1 Cileunyi

\begin{tabular}{llll}
\hline No. & Skor $(\mathrm{X})$ & Frekuensi $(\mathrm{F})$ & $\mathrm{F}(\mathrm{X})$ \\
\hline 1. & 6.5 & 2 & 13 \\
\hline 2. & 5.5 & 3 & 16.5 \\
\hline 3. & 5.0 & 2 & 10 \\
\hline 4. & 4.5 & 1 & 4.5 \\
\hline 5 & 4.0 & 3 & 12 \\
\hline 6 & 3.5 & 3 & 10.5 \\
\hline 7 & 3.0 & 5 & 15 \\
\hline 8 & 2.5 & 1 & 2.5 \\
\hline Jumlah & & $\sum=20$ & $\sum=84$ \\
\hline
\end{tabular}

Tabel 2. Distribusi Frekuensi Nilai Pascates Siswa Kelas XI Bahasa SMA Negeri 1 Cileunyi

\begin{tabular}{llll}
\hline No. & Skor $(\mathrm{Y})$ & Frekuensi $(\mathrm{F})$ & $\mathrm{F}(\mathrm{Y})$ \\
\hline 1. & 9.5 & 5 & 47.5 \\
\hline 2. & 9.0 & 2 & 18 \\
\hline 3. & 8.5 & 5 & 42.5 \\
\hline 4. & 8.0 & 3 & 24 \\
\hline 5. & 7.5 & 4 & 30 \\
\hline 6 & 7.0 & 1 & 7 \\
\hline Jumlah & & $\sum=20$ & $\sum=169$ \\
\hline
\end{tabular}

Berdasarkan table distribusi frekuensi nilai prates dan pascates di atas, dapat dihitung rata-rata dari prates ialah 4.2 dan pascates 8,45. Dari perhitungan tesebut, terlihat bahwa nilai rata-rata pascates lebih besar daripada prates yakni 8,45> 4,475 dengan selisih nilai sebesar 4 . Hal ini berarti ada kemajuan atau peningkatan hasil belajar siswa. Selain itu, dari pengujian sigujian signifikansi keberhasilan proses belajar mengajar membuat resensi drama yang ditonton dengan teknik think talk write. Diperoleh derajat kebebasan sebesar 19 dengan tingkat kepercayaan $95 \%$, ternyata thitung lebih besar daripada tabel, yakni $5.67>2.04$. Artinya, terdapat perbedaan yang signifikan antara hasil prates dan pascates pada siswa kelas XI SMAN 1 Cileunyi dalam pembelajaran membuat resensi drama dengan teknik think talk write. Hal ini menunjukkan bahwa teknik think talk write tepat digunakan dalam pembelajaran membuat resensi drama karena bisa meningkatkan kemampuan siswa dalam memperoleh hasil belajarnya.

\section{Pengujian Hipotesis}

Setelah melaksanakan penelitian mengenai membuat resensi drama yang ditonton dengan teknik think talk write pada siswa kelas XI SMAN 1 Cileunyi, penulis akan mengemukakan pengujian hipotesis. Adapun hipotesis yang penulis ajukan sebagai berikut.

1) Penulis mampu melaksanakan pembelajaran membuat resensi drama yang ditonton dengan teknik think talk write pada siswa kelas XI SMAN 1 Cileunyi.

2) Siswa kelas XI SMAN 1 Cileunyi mampu membuat resensi drama yang ditonton dengan tepat. 
3) Teknik think talk write tepat digunakan dalam pembelajaran membuat resensi drama yang ditonton pada siswa kelas XI Bahasa SMAN 1 Cileunyi.

Berdasarkan hasil analisis yang telah penulis laksanakan, maka hipotesis yang diajukan dapat dibuktikan sebagai berikut.

Hipotesis pertama dapat diterima. Hal ini dibuktikan pada hasil penilaian guru Sastra Indonesia mengenai persiapan dan pelaksanaan pembelajaran pada siswa kelas XI Bahasa SMAN 1 Cileunyi, penulis mendapatkan nilai rata-rata 3,69 dengan persentase $92,25 \%$. Dengan demikian penulis berhasil mengajarkan membuat resensi drama yang ditonton dengan teknik think talk write pada siswa kelas XI SMAN 1 Cileunyi.

Hipotesis kedua dapat diterima. Hal ini dapat dibuktikan dengan adanya peningkatan nilai rata-rata prates ke nilai rata-rata pascates. Nilai rata-rata prates 4,2 nilai rata-rata pascates 8,45 , peningkatannya sebesar 4,2 .

Hipotesis ketiga dapat diterima. Hal ini dibuktikan dengan hasil prates dan pascates. Dari hasil prates diperoleh nilai rata-rata 4,2 sedangkan nilai pascates sebesar 8,45. Dengan demikian, dari hasil prates ke pascates mendapatkan peningkatan sebesar 4,2. Melalui perhitungan statistik yang penulis lakukan, diperoleh thitung sebesar $5.67>$ tabel pada taraf signifikansi $5 \%$ yaitu 2.04 dengan derajat kebebasan 19. Hal ini menunjukkan hipotesis kerja $(\mathrm{Ha})$ diterima. Artinya ada perbedaan signifikan antara nilai prates dan pascates dalam pembelajaran membuat resensi drama dengan teknik think talk write.

Berdasarkan uraian di atas, dapat disimpulkan bahwa ketiga hipotesis yang penulis ajukan dapat diterima.

\section{SIMPULAN}

Peneliti mengemukakan beberapa simpulan berkaitan dengan penelitian yang telah dilakukan. Peneliti mampu melaksanakan pembelajaran membuat resensi drama dengan teknik think talk write pada siswa kelas XI Bahasa SMAN 1 Cileunyi. Hal ini terbukti berdasarkan hasil penilaian persiapan dan pelaksanaan pembelajaran membuat resensi drama dari guru mata pelajaran bahasa dan sastra Indonesia. Adapun hasil penilaian persiapan pembelajaran peneliti yaitu 3,7 dengan kategori nilai baik sekali (A). Kemudian, hasil penilaian pelaksanaannya 3,68, dengan kategori nilai baik sekali (A). Sesuai dengan kategori penilaian yang telah ditetapkan, maka persiapan dan pelaksanaan pembelajaran peneliti dapat dinyatakan baik. Artinya, penelitian yang dilakukan peneliti telah berjalan dengan baik.

Siswa kelas XI Bahasa SMAN 1 Cileunyi, mampu membuat resensi drama dengan teknik think talk write. Hal ini terbukti dari nilai rata-rata prates dan pascates. Nilai ratarata prates yaitu 4,2 sedangkan nilai rata-rata pascates 8,45 , dengan selisih nilai rata-rata prates dan pascates sebesar 4.2. Hasil ini membuktikan, bahwa kemampuan membuat resensi drama yang ditonton siswa kelas XI Bahasa SMAN 1 Cileunyi mengalami peningkatan.

Siswa kelas XI Bahasa SMAN 1 Cileunyi mampu membuat resensi drama dengan teknik think talk write. Hal ini terbukti dari hasil perhitungan statistik dan perhitungan taraf signifikasi perbedaan dua mean antara nilai prates dengan nilai pascates, diketahui thitung 5.67 $>$ tabel 2.04. Artinya, pembelajaran membuat resensi drama yang ditonton dengan teknik think talk write berhasil dengan baik. Dengan demikian, peneliti menyimpulkan bahwa teknik think talk write tepat digunakan dalam pembelajaran membuat resensi 
drama yang ditonton dengan teknik think talk write pada siswa kelas XI Bahasa SMAN 1 Cileunyi.

\section{REFERENSI}

Djuharie, O. P., \& Suherli. (2005). Panduan membuat karya tulis. Bandung: Yrama Widya.

Keraf, G. (1994). Komposisi. Jakarta: Nusa Indah.

Kosasih, E. (2012). Dasar-dasar keterampilan bersastra. Bandung: Yrama Widya.

Subana, M. (2009). Dasar-dasar penelitian ilmiah. Bandung: Pustaka Setia.

Tim Depdiknas. (2006). Kurikulum tingkat satuan pendidikan mata pelajaran bahasa Indonesia. Jakarta: Depdiknas.

Yamin, M., \& Ansari, B. I. (2009). Taktik mengembangkan kemampuan individual siswa. Jakarta: Gaung Persada Press. 